\title{
PENGARUH PUPUK FOSFAT TERHADAP PERTUMBUHAN, PRODUKSI, DAN MUTU BENIH KEDELAI (Glycine max L. Merrill) YANG DITANAM DI LAHAN SAWAH PADA MUSIM KEMARAU
}

\section{THE EFFECT OF PHOSPHATE FERTILIZER ON GROWTH, PRODUCTION, AND QUALITY OF SOYBEAN (Glycine max L. Merrill) PLANTED IN THE FIELD OF THE LATER SEASON}

\author{
Agustiansyah $^{1}$, Ermawati $^{2}$, Eko Pramono $^{1}$, \& A.T. Wibowo ${ }^{2}$ \\ ${ }^{1}$ Jurusan Agronomi dan Hortikultura Fakultas Pertanian Universitas Lampung \\ ${ }^{2}$ Jurusan Agroteknologi Fakultas Pertanian Universita Lampung \\ Jl. Prof. Dr. Soemantri Brojonegoro No. 1 Bandar Lampung 35145 \\ E-mail: agustiansyah.1972@fp.unila.ac.id
}

\begin{abstract}
This study aims (1) determine the optimum dose of phosphate fertilizer for three (3) soybean varieties in growth, production, and seed quality, (2) determine the interaction between increasing phosphate fertilizer and three soybean varieties on growth, production, and seed quality planted on fields July-September 2017. The treatment plan was arranged in factorial (3x5). The first factor is three soybean varieties (Anjasmoro, Grobogan, Burangrang), the second factor is five SP-36 fertilization levels (0, 100, 150, 200, and $250 \mathrm{~kg} \mathrm{ha}^{-1}$ ). Separation of the mean using the Orthogonal Comparison Test technique. The results of the study concluded that the SP-36 dose which gave a maximum yield of Grobogan Varieties 193-200 kg ha-1. Anjasmoro 182-189 $\mathrm{kg} \mathrm{ha}^{-1}$; and Burangrang 159-164 $\mathrm{kg} \mathrm{ha}^{-1}$. The growth, production, and quality of seeds of the three different varieties. Grobogan varieties are better than Anjasmoro and Burangrang varieties as indicated by the rate of seed filling, and the weight of 100 grains. Anjasmoro varieties are better than Burangrang shown by trifoliate leaves and amount of seeds. The growth and quality of the seeds of the three varieties did not differ on the variable level of leaf greenness, germination, and speed of germination. Meanwhile, optimum SP-36 fertilization results in better production of Grobogan varieties than Anjasmoro and Burangrang varieties, which are shown in plant weight and seed yield. Anjasmoro varieties are better than Burangrang in increasing their dry weight, leaf area, number of pods, and number of seeds.
\end{abstract}

Keywords: Dry season, Phosphate, Production, Soybean, Seeds.

\begin{abstract}
ABSTRAK
Penelitian ini bertujuan untuk (1) mengetahui dosis pupuk fosfat yang optimum untuk tiga (3) varietas kedelai dalam pertumbuhan, produksi, dan mutu benih, (2) mengetahui interaksi antara peningkatan pupuk fosfat dan tiga varietas kedelai terhadap pertumbuhan, produksi, dan mutu benih yang ditanam pada lahan sawah JuliSeptember 2017. Rancangan perlakuan disusun secara faktorial $(3 \times 5)$. Faktor pertama adalah tiga varietas kedelai (Anjasmoro, Grobogan, Burangrang), faktor kedua adalah lima taraf pemupukan SP-36 (0, 100, 150, 200, dan $250 \mathrm{~kg} / \mathrm{ha}$ ). Pemisahan nilai tengah menggunakan teknik Uji Perbandingan Orthogonal. Hasil penelitian menyimpulkan bahwa dosis SP-36 yang memberikan hasil maksimum Varietas Grobogan 193-200 kg/ha,
\end{abstract}


Anjasmoro 182-189 kg/ha; dan Burangrang 159-164 kg/ha. Pertumbuhan, produksi dan mutu benih ketiga varietas berbeda. Varietas Grobogan lebih baik daripada varietas Anjasmoro dan Burangrang yang ditunjukkan oleh laju pengisian biji, dan bobot 100 butir. Varietas Anjasmoro lebih baik daripada Burangrang ditunjukkan daun trifoliat dan jumlah biji. Pertumbuhan dan mutu benih ketiga varietas tidak berbeda pada variabel tingkat kehijauan daun, daya berkecambah, dan kecepatan berkecambah. Sementara itu pemupukan SP-36 optimum menghasilkan produksi dari Varietas Grobogan lebih baik daripada Varietas Anjasmoro dan Burangrang ditunjukkan pada bobot biji pertanaman dan hasil benih. Varietas Anjasmoro lebih baik daripada Burangrang dalam meningkatkan bobot kering berangkasan, luas daun, jumlah polong, dan jumlah biji.

Kata kunci: fosfat, kedelai, produksi, benih, musim kering

\section{PENDAHULUAN}

Kedelai (Glycine max L. Merrill) merupakan salah satu sumber pangan penting di Indonesia. Seiring dengan pertumbuhan jumlah penduduk, permintaan kedelai dari tahun ke tahun terus meningkat. Berbagai usaha dilakukan untuk meningkatkan produksi dan produkstivitas, seperti perluasan areal tanam (Sumarno et al., 2007), pengembangan kedelai tahan naungan (Kisman et.al, 2008), kedelai tahan kekeringan (Pienyani et al., 2015), kedelai resisten pada tanah masam (Kuswantoro et al., 2017).

Lahan sawah di Indonesia kebanyakan setiap tahun hanya dimanfaatkan untuk budidaya padi satu sampai dua kali saat musim hujan. Lahan sawah pada musim kemarau, memiliki potensi untuk dikembangkan untuk budidaya kedelai (Sumarno et al., 2007). Lahan sawah pada musim kemarau memiliki keunggulan memiliki keunggulan dalam kualitas penyinaran, intensitas penyinaran penuh tidak banyak terhalangi mendung, dan lama penyinaran kurang lebih 10 jam/ hari (Badan Meteorologi, Klimatologi, dan Geofisika/ BMKG, 2017). Namun lahan ini biasanya merupakan lahan kering masam yang memiliki beberapa kendala seperti kadar Al dapat ditukar dan fiksasi P tinggi, kandungan bahan organik, kapasitas tukar kation dan kejenuhan basa dan aktivitas biologi yang rendah (Hidayat dan Mulyani 2005; Hartatik dan Septyana, 2012).

Fosfat $(\mathrm{P})$ sangat dibutuhkan tanaman kedelai dan menjadi faktor pembatas produksi terbesar setelah nitrogen (Suwarno, 1991). Peranan pupuk fosfat merupakan unsur hara yang penting dan berkaitan dengan produksi dan mutu benih kedelai. Pemberian hara fosfat dapat memacu pertumbuhan generatif sehingga dapat meningkatkan hasil biji per satuan luas dan mutu benih kedelai yang tinggi. Rasyid (2015) menyatakan bahwa hara fosfat disimpan paling banyak dalam biji dan menentukan vigor benih dan daya simpan kedelai. Kekurangan fosfat dapat menyebabkan perkembangan akar lambat sehingga resisten terhadap kekeringan dan terhambatnya ketersediaan usur hara bagi tanaman. Dosis pupuk yang tepat untuk masingmasing varietas akan menghasilkan pertumbuhan, produksi, dan mutu benih yang optimum

Pemilihan varietas juga sangat penting dilakukan untuk meningkatkan produktivitas kedelai dan 
menyesuaikan kebutuhan pasar. Kedelai berumur sedang memiliki jumlah polong dan biji lebih banyak dibandingkan dengan yang genjah, namun lahan sawah musim kemarau memiliki kemumungkinan cekaman air saat pengisian polong (Rahajeng dan Muclish, 2013; Setyani et al., 2017). Penelitian bertujuan untuk memperoleh informasi mengenai dosis pupuk fosfat yang optimum untuk pertumbuhan, produksi, dan mutu benih tanaman kedelai; membandingkan pertumbuhan, produksi, dan mutu benih dari tiga varietas kedelai; serta mengetahui interaksi antara peningkatan pupuk fosfat dan tiga varietas kedelai terhadap pertumbuhan, produksi, dan mutu benih yang ditanam pada lahan sawah musim kemarau.

\section{BAHAN DAN METODE}

Penelitian ini dilaksanakan dalam dua tahap yaitu produksi benih di lapang dan pengujian mutu benih di laboratorium. Produksi dimulai sejak bulan JuliSeptember 2017, di lahan sawah irigasi Desa Sritejokencono, Kecamatan Kotagajah, Kabupaten Lampung Tengah dengan koordinat 50'43.1068"S, $105^{\circ} 21^{\prime} 01.4^{\prime \prime} \mathrm{E}$ dan ketinggian tempat kurang lebih 50 meter diatas permukaan laut. Pengujian benih dilakukan pada bulan Oktober 2017 di Laboratorium Benih dan Pemuliaan Tanaman Universitas Lampung. Rancangan perlakuan disusun secara faktorial (3x5). Faktor pertama adalah varietas kedelai yaitu Anjasmoro (V1); Grobokan (V2); Burangrang, (V3). Faktor kedua adalah dosis SP-36 yaitu $0 \mathrm{~kg} / \mathrm{ha}\left(\mathrm{P}_{0}\right)$, $100 \mathrm{~kg} / \mathrm{ha}\left(\mathrm{P}_{1}\right), 150 \mathrm{~kg} / \mathrm{ha}\left(\mathrm{P}_{2}\right), 200 \mathrm{~kg} / \mathrm{ha}\left(\mathrm{P}_{3}\right)$, dan $250\left(\mathrm{P}_{4}\right)$. Perlakuan diterapkan dalam rancangan kelompok teracak sempurna. Pengelompokan didasarkan pada kontur lahan (tinggi, sedang, rendah). dan setiap perlakuan diulang sebanyak tiga kali. Homogenitas ragam diuji dengan Uji Bartlett dan aditivitas data diuji dengan Uji Tukey, apabila uji asumsi terpenuhi maka pemisahan nilai tengah dilanjutkan dengan Uji Perbandingan Orthogonal pada taraf nyata 5 dan $1 \%$.

Persiapan lahan. Penyiapan lahan secara mekanis menggunakan traktor rotarry, kemudian dilakukan blocking berdasarkan ketinggian lahan, dilanjutkan dengan pembuatan petak pada tiap block sebanyak 15 petak dengan ukuran $5 \mathrm{~m}$ x $6 \mathrm{~m}$ dengan jarak antar petak $50 \mathrm{~cm}$. Pembuatan lubang tanam menggunakan tugal dengan jarak tanam $25 \times 50 \mathrm{~cm}$.

Penanaman. Sebelum ditanam, benih dicampur dengan rhizobium dengan cara: 200 gram benih dibasahi dengan air kemudian ditaburkan 1 gram rhizobium dan diaduk sampai rata. Pemupukan fosfat dengan menggunakan SP-36 seperti pada perlakuan. Pupuk Urea dengan dosis $50 \mathrm{~kg} / \mathrm{ha}$. Pupuk KCl dengan dosis $100 \mathrm{~kg} / \mathrm{ha}$. Pupuk diberikan saat tanaman berumur 1 MST dengan cara ditugal pada setiap dua lubang tanam satu lubang pupuk dan kemudian ditutup dengan tanah.

Pemeliharaan yang dilakukan berupa pengendalian gulma, hama, dan penyakit yang disesuaikan dengan kondisi di lapang. Pada masa pertumbuhan tanaman dilakukan pengamatan dengan variabel yang diamati meliputi tinggi tanaman, jumlah daun trifoliate, jumlah buku, luas daun, tingkat kehijauan daun, dan bobot kering berangkasan.

Panen dilakukan dengan menyesuaikan kondisi 
tanaman,polong telah mencapai masak panen yang ditandai oleh polong dan batang berwarna kecoklatan lebih dari $90 \%$ dan daun telah luruh lebih dari $95 \%$. Kemudian benih dipisahkan dari polongnya dan dilanjutkan penggeringan secara alami dengan dijemur dibawah terik matahari sampai pada kadar air 9-10\%. Variabel yang diamati untuk komponen produksi meliputi jumlah polong total, jumlah biji pertanaman, laju pengisian biji, dan produksi benih tiap perlakuan. Pengujian mutu benih. Pengujian mutu benih meliputi daya berkecambah, kecepatan berkecambah, dan bobot 100 butir

\section{HASIL DAN PEMBAHASAN}

\section{Hasil Penelitian}

\section{Pertumbuhan Tanaman di Lapang}

Tinggi tanaman. Tanggapan varietas kedelai pada tinggi tanaman tidak bergantung pada dosis pupuk SP-36 yang berbeda. Rata-rata tinggi varietas Anjasmoro dan Burangrang adalah 83,97 cm, sedangkan Grobogan memiliki tinggi 31,25\% lebih rendah yaitu $57,72 \mathrm{~cm}$. Burangrang memiliki tinggi sebesar 88,30 cm, sedangkan Anjasmoro 9,81\% lebih rendah. Pemberian berbagai dosis SP-36 menghasilkan tinggi tanaman masih relatif sama (Tabel 1).

Jumlah daun trifoliat. Tanggapan varietas kedelai pada daun trifoliat tidak bergantung pada dosis pupuk SP-36 yang berbeda. Rata-rata jumlah daun trifoliat Varietas genjah Grobogan sebanyak 20,53 helai, dan masih relatif sama dibandingkan dengan Anjasmoro dan Burangrang dengan rata-rata sebanyak 19,95 helai; sedangkan daun trifoliat Anjasmoro sebayak 20,76 helai sedangkan Burangrang 8,44\% lebih sedikit yaitu 19,15. Pemberian berbagai dosis SP-36 menghasilkan daun trifoliat masih relatif sama (Tabel 1).

Jumlah buku utama. Tanggapan varietas kedelai terhadap jumlah buku tidak bergantung pada dosis pupuk SP-36 yang berbeda. Rata-rata jumlah buku Varietas Anjasmoro dan Burangrang sebayak 14,97 sedangkan Grobogan lebih sedikit 19,94\% yaitu

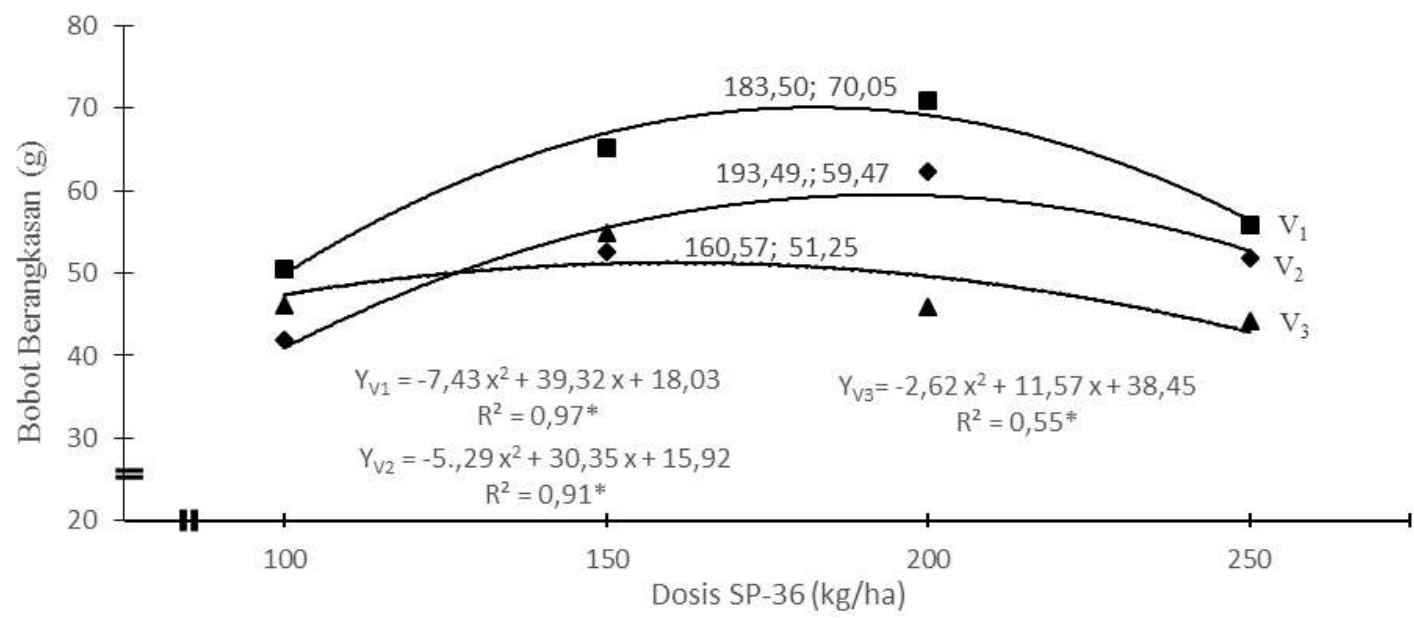

Gambar 1. Pengaruh pupuk fosfat terhadap bobot kering berangkasan pada tiga varietas kedelai.

Keterangan: V1 = Anjasmoro ( \%; sedang); V2 = Grobogan (f\&;genjah); V3 = Burangrang ( ${ }^{2 \%}$;sedang) 
Tabel 1. Rekapitulasi pengaruh pupuk fosfat terhadap pertumbuhan, produksi, dan mutu benih tiga varietas kedelai.

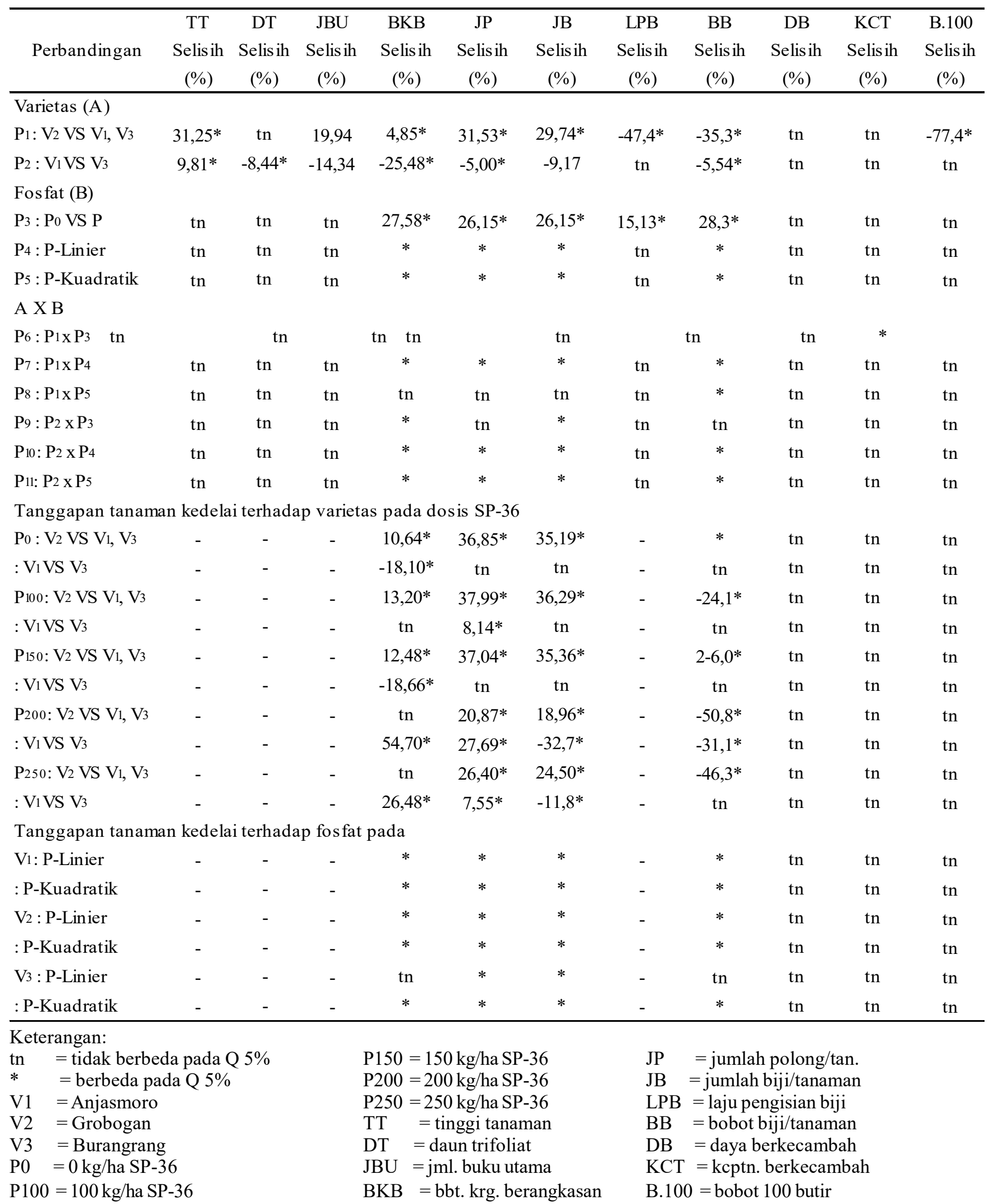




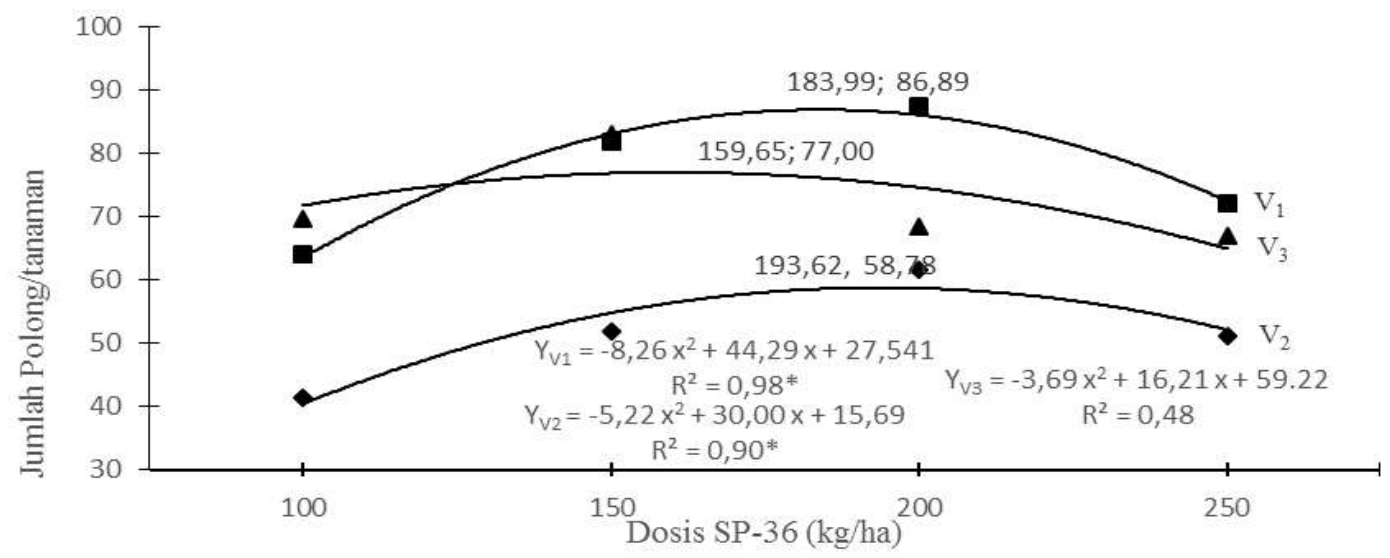

Gambar 2. Pengaruh pupuk fosfat terhadap jumlah polong per tanaman pada tiga varietas kedelai.

Keterangan: V1 = Anjasmoro ( \%; sedang); V2 = Grobogan (f\&;genjah); V3 = Burangrang ( ${ }^{2 \%}$;sedang)

11,99 buku; sedangkan Anjasmoro memiliki jumlah buku 15,97 atau lebih bayak 14,34\% daripada Burangrang yaitu 13,7 buku. Pemberian dosis pupuk SP-36 sampai $250 \mathrm{~kg} /$ ha menghasilkan jumlah buku masih relatif sama (Tabel 1).

Bobot kering berangkasan. Pemberian dosis pupuk SP-36 mempengaruhi bobot kering berangkasan tergantung pada berbagai varietas. Pada Varietas Anjasmoro, bobot berangkasan maksimum tercapai pada dosis $183,50 \mathrm{~kg} /$ ha sebanyak 70,05 gram. Pada Grobogan bobot berangkasan maksimum pada $193,49 \mathrm{~kg} /$ ha sebanyak 59,47 gram. Pada Burangrang, bobot berangkasan maksimum pada pemupukan $160,57 \mathrm{~kg} /$ ha sebanyak 51,25 gram (Gambar 1).

\section{Produksi Benih di Lapang Jumlah polong} total. Pemberian dosis pupuk SP-36 mempengaruhi jumlah polong tergantung pada berbagai varietas. Peningkatan dosis pupuk SP-36 sampai $250 \mathrm{~kg} / \mathrm{ha}$ pada masing-masing Varietas Anjasmoro, Grobogan, dan Burangrang mampu meningkatkan jumlah polong secara kuadratik. Pada varietas Anjasmoro, jumlah polong maksimum tercapai pada dosis $183,99 \mathrm{~kg} / \mathrm{ha}$ yaitu 86,89 polong. Pada varietas Grobogan, jumlah polong maksimum tercapai pada dosis $193,62 \mathrm{~kg} / \mathrm{ha}$ sebanyak 58,78 polong. Pada varietas Burangrang, jumlah polong maksimum tercapai pada dosis 159,65 $\mathrm{kg} /$ ha sebanyak 77,00 polong (Gambar 2).

Jumlah biji per tanaman. Pemberian dosis pupuk SP-36 mempengaruhi jumlah biji per tanaman tergantung pada berbagai varietas (Tabel 1). Pada Varietas Anjasmoro, jumlah biji maksimum tercapai pada dosis $183,99 \mathrm{~kg} /$ ha sebanyak 250,24 biji. Pada Grobogan, jumlah biji maksimum tercapai pada dosis 193,62 kg/ha sebanyak 170,46 biji. Pada Burangrang, jumlah biji maksimum tercapai pada dosis $159,66 \mathrm{~kg} /$ ha sebanyak 213,28 biji.

Bobot biji. Pemberian dosis pupuk SP-36 mempengaruhi bobot biji per tanaman tergantung pada berbagai varietas (Tabel 1). Peningkatan dosis pupuk P sampai $250 \mathrm{~kg} /$ ha pada masing-masing Varietas Anjasmoro, Grobogan, dan Burangrang mampu 


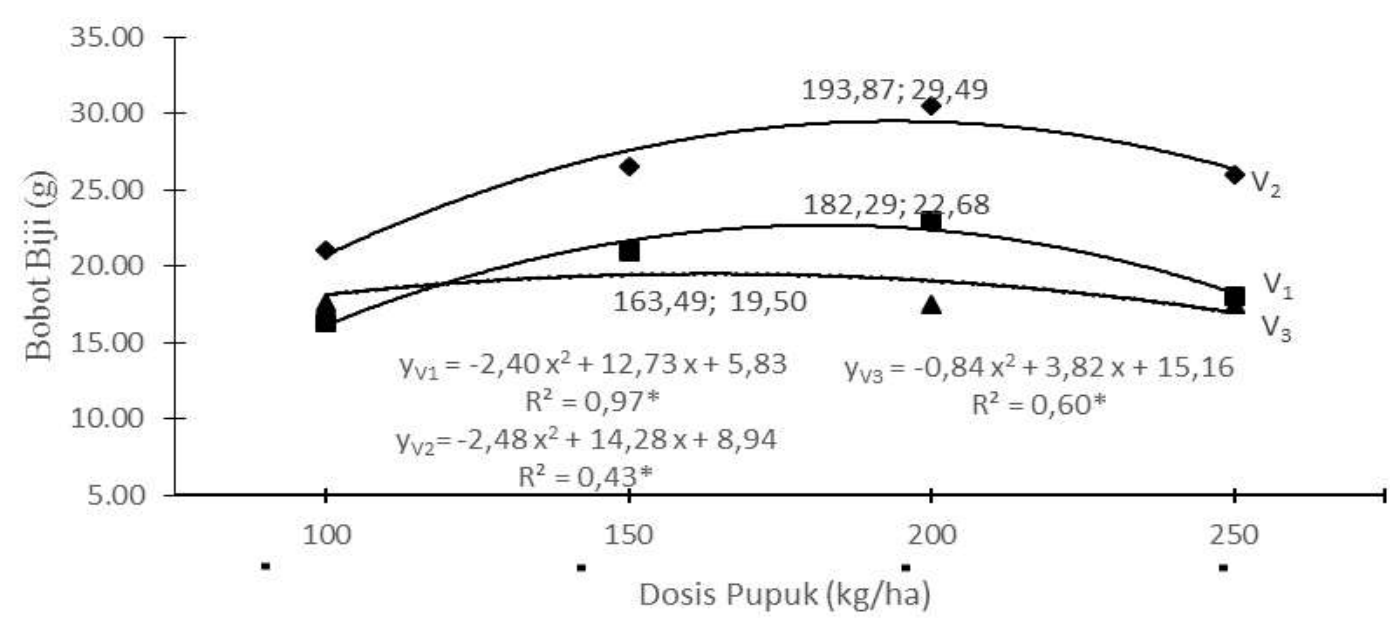

Gambar 3. Pengaruh pupuk fosfat terhadap bobot biji pada tiga varietas kedelai.

Keterangan: V1 = Anjasmoro ( \%; sedang); V2 = Grobogan (f\&;genjah); V3 = Burangrang ( ${ }^{2 \%} \%$;sedang)

meningkatkan bobot biji secara kuadratik. Pada Varietas Anjasmoro, bobot biji maksimum tercapai pada dosis $182,29 \mathrm{~kg} /$ ha sebanyak 22,68 gram. Pada Grobogan, bobot biji maksimum tercapai pada dosis 193,87 kg/ha sebanyak 29,49 gram. Pada Burangrang, bobot biji maksimum tercapai pada dosis $163,49 \mathrm{~kg} /$ ha sebanyak 29,50 gram (Gambar 3).

Laju pengisian biji. Tanggapan varietas kedelai terhadap laju pengisian biji tidak bergantung pada dosis pupuk SP-36 yang berbeda. Laju pengisian biji Varietas Anjasmoro dan Burangrang sebesar 0,50 gram/hari/tanaman atau lebih rendah $47,36 \%$ daripada Grobogan (0,95 gram/hari/tanaman); sedangkan Anjasmoro (0,49 gram/hari/tanaman) dan Burangrang (0,51 gram/hari/tanaman) memiliki laju pengisian biji yang masih relatif sama. Pemberian pupuk SP-36 memberikan laju pengisian sebesar 0,67 gram/hari/ tanaman atau yang lebih baik $15,13 \%$ daripada tanpa memberikan pupuk (Tabel 2).

\section{Mutu Benih}

Daya Berkecambah. Daya berkecambah yang dihasilkan dari berbagai varietas tidak tergantung pada dosis pupuk SP-36 yang berbeda. Daya berkecambah yang dihasilkan dari berbagai varietas masih relatif sama yaitu Ajasmoro sebesar 97,73\%; Grobogan 98,53\% ; dan Burangrang 97,53\%. Pemberian berbagai dosis SP-36 menghasilkan daya berkecambah tidak berbeda (Tabel 1).

Kecepatan berkecambah. Kecepatan perkecambahan yang dihasilkan dari berbagai varietas tidak tergantung pada dosis pupuk SP-36 yang berbeda. Kecepatan perkecambahan yang dihasilkan dari berbagai varietas masih relatif sama yaitu Anjasmoro sebesar 45,10\%; Grobogan sebesar 45,65\%; dan Burangrang sebesar 44,93\%.

Bobot 100 butir. Tanggapan varietas tanaman kedelai pada bobot 100 butir tidak bergantung pada dosis P yang berbeda. Bobot 100 butir Varietas Anjasmoro dan Burangrang sebesar 10,10 gram atau 
lebih rendah 77,35\% daripada Varietas Grobogan yang memiliki bobot 17,91 gram; sedangkan bobot 100 butir Anjasmoro (10,00 gram) dan Burangrang (10,20 gram) relatif tidak berbeda. Pemberian dosis SP-36 menghasilkan bobot 100 butir masih relatif sama (Tabel 1).

\section{Pembahasan}

Hasil penelitian menujukkan bahwa pemberian dosis pupuk SP-36 bergantung pada varietas dalam mempengaruhi pertumbuhan dan produksi, tetapi perlakuan belum meningkatkan mutu benih kedelai. Varietas yang berumur sedang lebih baik daripada genjah (Grobogan) pada dosis SP-36 tertentu dalam meningkatkan pertumbuhan tanaman. Pertumbuhan yang dimiliki varietas sedang lebih baik karena sifat genetik yang dimiliki, Anjasmoro merupakan kedelai unggul dengan tinggi tanaman 64-68 cm, jumlah buku cabang utama 12,9-14,8; dan daya hasil mencapai 2,03-2,35 t/ha; Burangrang dengan umur panen 8082 hst memiliki tinggi 60-70 cm, jumlah buku 13-16, dengan percabangan 1-2 (Balitkabi, 2016). Pertumbuhan yang lebih baik varietas sedang juga lebih sedikit dalam membutuhkan SP-36. Hal tersebut diduga faktor genetik sehingga penyerapan unsur hara lebih efektif dan bertahap sehingga lebih sedikit membutuhkan pupuk P. Varietas genjah membutuhkan SP-36 yang lebih banyak meskipun fase vegetatifnya yang lebih pendek tetapi kondisi lingkungan sesuai dengan syarat tumbuh maka kedelai ini membutuhkan unsur fosfat lebih banyak. Hal tersebut sejalan dengan hasil penelitian Kurniawan et al. (2014) bahwa kebutuhan P Varietas Grobogan sebesar 50 kg/ha,
Anjasmoro dan Burangrang $25 \mathrm{~kg} / \mathrm{ha}$.

Pemberian dosis sampai pada $250 \mathrm{~kg} / \mathrm{ha} \mathrm{SP-}$ 36 belum meningkatkan mutu benih kedelai pada semua varietas, meskipun demikian viabilitas benih cukup tinggi yang ditunjukkan dengan daya berkecambah rataratanya di atas $97 \%$. Hal tersebut diduga karena benih yang diuji dipanen saat masak fisiolohis dan belum mengalami kemunduran karena proses penyimpanan. Menurut Ilyas (2013), benih yang dipanen pada saat masak fisiologis akan memiliki bobot kering yang optimum sehingga akan memiliki mutu benih yang sangat tinggi. Sedangkan menurut penelitian Rasyid (2015) bahwa waktu penyimpanan satu bulan, daya berkecambah dan kecepatan perkecambahan benih tidak berbeda pada semua ukuran besar benih kedelai. Meskipun kedelai berumur sedang memiliki jumlah polong dan biji yang lebih baik daripada varietas genjah juga didukung oleh bobot kering berangkasan yang tinggi pada berbagai dosis pupuk SP-36, tetapi kedelai ini tidak dapat memaksimalkan hasil fotosintat ke biji. Hal ini dapat terlihat dari mutu fisik bobot 100 butir. Hasil penelitian menujukkan bobot 100 butir Anjasmoro sebesar 9,97 gram; dan Burangrang sebesar 10,20 gram; Grobogan tertinggi dengan 17,99 gram. Varietas berumur sedang tidak mampu mentransfer secara optimal hasil fotosintat tersebut diduga akibat cekaman cuaca yang terjadi. Berdasarkan data iklim Badan, Meteorologi, Klimatologi dan Geofisika (2017) bahwa curah hujan pada Juli-Agustus 2017 kurang dari $100 \mathrm{~mm}$. Tanaman palawija seperti kedelai membutuhkan air berkisar 350 - $400 \mathrm{~mm} / 3,5$ bulan (Djaenudin et al., 2011). 
Kedelai berumurgenjah(Grobogan) memiliki potensi yang lebih baik untuk menghasilkan produktivias tinggi yang ditunjukkan pada variabel bobot biji dan hasil benih kedelai yang ditanam pada lahan sawah musim kemarau pada berbagai dosis pupuk fosfat. Meskipun memiliki bobot berangkasan yang lebih kecil tetapi kedelai genjah dapat memaksimalkan penyinaran yang sangat baik dan curah hujan sedikit tersebut, sehingga hasil fotosintat dapat ditransfer kedalam benih secara optimal. Menurut Sutopo (1988) kedelai yang mengalami cekaman air saat pengisian polong akan menjadikan ukuran kedelai lebih kecil. Hal tersebut menjadi keuntungan untuk varietas berumur genjah, karena memiliki sifat genetik masa vegetatif yang singkat.. Pemupukaan P dalam bentuk ion fosfat dibutuhkan oleh tanaman untuk pembelahan dan pembesaran sel pada jaringan meristem, kemudian meristem akan menghasilkan selsel baru di ujung akar atau batang yang mengakibatkan tumbuhan bertambah tinggi atau panjang (Gardner $e t$ al., 1991).

Pertumbuhan akar yang tinggi menjadikan tanaman kedelai pada tingkat pemupukan $\mathrm{P}$ yang optimum berpotensi dapat memperkuat vigor tanaman dalam menghadai kekeringan. Menurut Sumarno et al. (2007) pemupukan P meningkatkan berat biji per plot dan berat biji per hektar, pemberian pupuk $\mathrm{P}$ yang sangat tinggi semakin menurunkan hasil biji dikarenakan terjadi kopetisi dengan unsur lain terutama $\mathrm{Zn}$ dan Fe. Pada penelitian ini diketahui kebutuhan SP-36 untuk masing-masing varietas berbeda, untuk mendapatkan bobot biji dan hasil benih per petak yang maksimum,
Grobogan membutuhkan pupuk SP-36 terbesar yaitu sekitar 193-200 kg/ha; Anjasmoro 182-189 kg/ha; Burangrang 159-164 kg/ha. Laju pengisian biji varietas genjah lebih baik, hal tersebut menjadikan bobot biji semakin tinggi, sehingga mutu benih bobot 100 butir dapat dipertahankan sesuai dengan deskripsi. Menurut Yunita(2010) laju pengisian biji adalah besarnya asimilat yang ditransfer tanaman kedalam biji, semakin besar laju pengisian biji dengan waktu yang relatif lebih lama akan menghasilkan produksi yang lebih banyak.

\section{KESIMPULAN}

Dosis SP-36 yang memberikan hasil maksimum Varietas Grobogan 193-200 kg/ha, Anjasmoro 182-189 kg/ha; dan Burangrang 159-164 $\mathrm{kg} / \mathrm{ha}$. Pertumbuhan, produksi dan mutu benih ketiga varietas berbeda. Varietas Grobogan lebih baik daripada varietas Anjasmoro dan Burangrang yang ditunjukkan oleh laju pengisian biji, dan bobot 100 butir. Varietas Anjasmoro lebih baik daripada Burangrang ditunjukkan daun trifoliat dan jumlah biji. Pertumbuhan dan mutu benih ketiga varietas tidak berbeda pada variabel tingkat kehijauan daun, daya berkecambah, dan kecepatan berkecambah. Sementara itu pemupukan SP-36 optimum menghasilkan produksi dari Varietas Grobogan lebih baik daripada Varietas Anjasmoro dan Burangrang ditunjukkan pada bobot biji pertanaman dan hasil benih. Varietas Anjasmoro lebih baik daripada Burangrang dalam meningkatkan bobot kering berangkasan, luas daun, jumlah polong, dan jumlah biji. 


\section{DAFTAR PUSTAKA}

Badan Meteorologi, Klimatologi dan Geofisika. 2017.

Laporan Iklim Harian. http:// dataonline.bmkg.go.id/data_iklim. [diakses 10 juli 2018].

Balitkabi. 2016. Deskripsi Varietas Unggul Kedelai 1918-2016.http://balitkabi.litbang. pertanian.go. id/wpcontent/uploads/2016/09/ kedelai.pdf. [diakses 20 Januari 2018].

Djaenudin, D., Marwan, H. Subagjo, H, dan Hidayat, H. 2011. Petunjuk Teknis Evaluasi Lahan untuk Komoditas Pertanian. Balai Besar Sumber Daya Lahan Pertanian. Bogor. 166 hlm.

Gardner, F.P., Pearce, R.B., and Mitchell., R.L. 1991. Fisiologi Tanaman Budidaya. Terjemahan $\mathrm{H}$. Susilo. UI Press. Jakarta.

Hartatik, W dan Septiyana. 2012. Ameliorasi dan Pemupukan untuk Peningkatan Produktivitas Kedelai di Lahan Suboptimal. Prosiding Seminar Nasional Teknologi Pemupukan dan Pemulihan Lahan Terdegradasi. Bogor 29-30 Juni 2012. Badan Penelitian dan Pengembangan Pertanian, Kementerian Pertanian.

Hidayat, Adan Mulyani, A. 2005. Lahan Kering Untuk Pertanian dalam buku Teknologi Pengelolaan Lahan Kering. Pusat Penelitian dan Pengembangan Tanah dan Agroklimat. Badan Penelitian dan Pengembangan Pertanian, Departemen Pertanian.

Ilyas, S. 2013. Ilmu dan Teknologi Benih: Teori dan Hasil-hasil Penelitian. Bogor: IPB Press. Pp 138.
Kisman, Trikoesoemaningtyas, Sobir, Khumaida, N. dan Sopandi, D. 2008. Pola Pewarisan Adaotasi Kedelai (Glycine max L. Merril) terhadap Cekaman Naungan Berdasarkan Karakter Morfo-Fisiologi Daun. Bul. Agron. (36)1:1-7.

Kurniawan,S., A. Rasyat, dan Wardati. 2014. Pengaruh Pemberian Pupuk Fosfor Terhadap Pertumbuhan Beberapa Varietas Kedelai. Jurnal Faperta. 1(2) : 10-17.

Kuswantoro, H.,Sutrisno, Supeno, A. 2017. Keragaan Agronomi Galur-galur Kedelai Potensial pada Dua Agroekologi Lahan Kering Masam. J. Agron. Indonesia. 45(1):23-29.

Pienyani, R., Ghulamahdi, M., Khumaida, N. 2015. Respon Anatomi dan Fisiologi Akar Kedelai terhadap Cekaman Kekeringan J. Agron. Indonesia. 43(3):186-192.

Rahajeng, W., dan Muclish, A.M. 2013. Varietas Kedelai Genjah. Bulettin Palawija 26: 91-100.

Rasyid, H. 2015. Peningkatan Produktivitas dan Mutu Benih Kedelai Varietas Hitam Unggul Nasional sebagai Fungsi Jarak Tanam dan Pemberian Dosis Pupuk P. Jurnal Gamma.8 (2):43-63.

Setyani. S., Siti. N., dan Eliyana. 2017. Evaluasi Sifat Kimia dan Sesari Tempe Kedelai-Jagung dengan Berbagai Konsentrasi Ragi Raprima dan/berbagai Formulasi.Jurnal Teknologi Industri \& Hasil Pertanian. 22(2): 85-98.

Sumarno, Suyamto, Widjono, A., Hermanto, dan Kasim, H., 2007. Kedelai Teknik Produksi dan Pengembangan. Pusat Penelitian dan Pengembangan Tanaman Pangan. Bogor. 521 hlm

Sutopo, L. 1988. Teknologi Benih. Cetakan Kedua. Jakarta :CV. Rajawali. 25-60 hlm. 
Suwarno, F. C. 1991. Akumulasi dan Pengaruh Fosfor terhadap Viabilitas Benih. J. Keluarga Benih. 2(2): 7-53.

Yunita, R. 2010. Uji Daya Hasil Lanjutan Galur-galur Kedelai Toleran Naungan di Bawah Tegakan Karet Rakyat di Desa Sebapo Kabupaten Muaro Jambi. Skripsi. Institut Pertanian Bogor. 